\title{
Article
}

\section{Correlation between nurse-patient interaction and readiness to care for post-treated heart failure patients in the intensive care room Malang, Indonesia}

\author{
Alfrina Hany, Ratih Arum Vatmasari \\ School of Nursing, Faculty of Medicine, Universitas Brawijaya, Malang, Indonesia
}

\begin{abstract}
Background: The number of people with heart failure significantly increases every year.

Therefore, this study aims to determine the nurse-patient interaction capable of providing adequate care to post-treated heart failure patients in intensive care rooms.

Design and Methods: This is a cross-sectional study with the consecutive sampling method used to obtain data from 100 posttreatment heart failure patients in intensive care rooms. PPIQ (Patient Professional Interaction Questionnaire) was used to measure nurse-patient interactions, while Self-care readiness was determined using the SCHFI (Self-Care Heart Failure Instrument).

Result: The result showed that there is a significant correlation between nurse-patient interactions and their readiness to care for post-treated heart failure patients in intensive care with a Pearson correlation value of $0.000(\mathrm{p}=0.05)$. Furthermore, both variables have a moderate and positive correlation strength and with a correlation coefficient value of 0.557 .

Conclusions: The yearly increase in the number of re-hospitalized patients in hospitals can be reduced with an increase in nursepatient interaction. This enables patients to have the ability to take proper care of themselves after leaving the hospital.
\end{abstract}

\section{Introduction}

Heart failure is a chronic disease that affects $2-3 \%$ of the global population. ${ }^{1}$ In Indonesia, the prevalence of heart disease continues to increase every year, with a rehospitalization rate of $29 \%{ }^{2}$ According to the results of a preliminary study, a total of 49 people were re-hospitalized due to heart failure from May-July 2019. One of the major causes of rehospitalization is a lack of adequate knowledge on self-care at home, due to the low interaction between nurses and patients. ${ }^{3}$ Knowledge is a factor of readiness which is important in building effective patient self-care behavior in order to achieve self-readiness. ${ }^{4}$ There are 4 components associated with patient-centered care, one of which is participation, where nurses need to interact with patients and prepare them for self-care. ${ }^{5}$ The advantage of the Patient Centered-Care practice is that it increases their health knowledge, self-care behavior, satisfaction rate and quality of life. ${ }^{6}$ Therefore, providing high-quality care is characterized by good interaction between nurses and patients. $^{7}$ This interaction is important in order to perform patient self-management abilities. ${ }^{8}$ Cramm and Nieboer stated that the interactions between nurses and patients in the context of a disease management program were lower with other health professional. ${ }^{9}$ These interactions have been identified as critical points in supporting patient self-management skills. ${ }^{8}$ Communication interaction in the ICU between nurses and patients is relatively low, and this is because it is commonly oriented to actions. ${ }^{10}$ This study was carried out to determine the correlation of interactions between nurses and patients on post-treatment heart failure patient readiness at Intensive Care Rooms in Malang.

\section{Design and Method}

This is a cross-sectional study with the consecutive sampling method used to obtain data from 100 post-treatment heart failure patients in intensive care rooms. The research was carried out from 1 November - 12 December 2019 in the intermediate care room in Malang, with the Patient-Professional Interaction Questionnaire by Casu et al. used to measure nurse-patient interactions. ${ }^{5}$ Meanwhile, the modified Indonesian version of SelfCare Heart Failure Index (SCHFI) was used to measure the readiness of patients to take care of themselves. ${ }^{11}$ All participants in this study signed an informed consent form, and the data were analyzed using descriptive statistics. Furthermore, the correlation between the two variables was analyzed using the Pearson correlation test with CI 95\%.

\section{Results and Discussions}

Demographic characteristics consist of gender/sex, age, education level, job status, duration of heart failure, the experience of having received heart failure information, and desire to improve quality of life. Table 1 shows the demographic characteristics of

Significance for public health

Patient-centered care approach is an important strategy used by nurses to achieve patient self-readiness. Studies have shown that the interaction between nurses and patients using a patient centered care approach helps patients increase their knowledge and ability to care for themselves. Increasing self-care readiness tends to reduce the rehospitalization rate of patients with heart failure. Therefore, this study determines the correlation between Nurse-Patient Interaction and Readiness to Care for Post-Treated Heart Failure Patients in the Intensive Care Rooms located in Malang. 
the respondents in this study, which comprises of 67 men and 33 women. A total of $35(35 \%)$ people were in their middle age (4559 years), and based on educational level, 33 people (33\%) had a high school education. In terms of those that are still working a total of 50 people was obtained. Approximately 58 people $(58 \%)$ had experienced heart failure for less than 1 year, while 73 people $(73 \%)$ never received information on this disease. All respondents have a desire to improve their quality of life (100\%).

Table 2 shows that nurse-patient interaction and self-readiness have a mean value of $45.27 \mathrm{SD} \pm 7.678$ and $50.91 \mathrm{SD} \pm 10.581$. The result of the Pearson correlation test of nurse-patient interaction and self-care readiness was 0.000 , thereby indicating a correlation between nurse-patient interactions with readiness to self-care with a coefficient of 0.557 . All data analysis was carried out using SPSS version 25 . The study shows that the majority of respondents who experience heart failure are male, as much as $67 \%$. According to Sekarsari lifestyle can affect the occurrence of heart failure. The lifestyle carried out in male patients, such as smoking and drinking coffee, can cause plaque formation in blood vessels which is a risk factor for heart failure. ${ }^{12}$ Most respondents are in middle age (4559 years) as many as $35 \%$. As you get older, the organs in the body experience progressive dysfunction and cause a decrease in function and affect the homeostasis in the body. ${ }^{13}$ The respondents in this study had education the last high school, which is as much as $33 \%$. A person's education level can affect their knowledge and ability to behave in a healthy manner, especially in treating themselves from their illness. ${ }^{14}$ Respondents who never received information about heart failure were $73 \%$. Where this health education can strengthen and build effective self-care behavior in heart failure patients. ${ }^{15}$ This health information can be obtained through self-search or from health workers. ${ }^{16}$

This study found that demographic characteristics did not affect nurse-patient interaction, which is in line with the research carried out by Gremigni et al. which stated that there are no significant differences in interactions between age groups and gender. ${ }^{17}$ However, in everyday life, people with education, knowledge, or skills interact more easily compared to others. Studies have shown that there are significant differences in interactions with patients with a higher level of education, which provides a different understanding in understanding the information that has been provided. ${ }^{5,16,18}$ The readiness to self-care is influenced by demographic characteristics, such as education level, duration of heart failure and information on heart failure treatment. In this study, respondents with high school education level and duration of heart failure above 5 years had better self-care readiness than others. Based on the level of education, the respondents with high school education level have better readiness, and this is because the level of education influences a person's behavior in seeking treatment for a disease, as well as choosing and deciding on an action or therapy to be undertaken. ${ }^{19,20}$ Furthermore, those that suffered from heart failure for more than 5 years had better preparedness. This is in accordance with the principles of readiness, which stated that experiences have a positive influence on readiness. ${ }^{4}$ The experience of suffering from heart failure is proven to increase patient knowledge in terms of signs of the disease, therefore, this tends to affect the ability to care for oneself. ${ }^{6}$ Respondents that had received information on heart failure from health professionals, family, neighbors and other resources have the readiness to care for themselves better. Other studies have stated that the level of education affects a person in their care-seeking behavior. ${ }^{20}$ In addition, information and experiences with a disease shape attitudes and abilities in self-care. ${ }^{21}$ In addition, nurses need the information necessary to understand patient needs and can increase patient participation in care. ${ }^{22}$

The bivariate analysis using the Pearson correlation test (Table 3 ) indicates that there is a relationship between the interaction of patient nurses and the readiness to care for themselves in posttreatment heart failure patients in the intensive care room. The

Table 1. Demographic characteristic.

\begin{tabular}{|c|c|c|}
\hline Characteristics & n & $\%$ \\
\hline \multicolumn{3}{|l|}{ Sex } \\
\hline Men & 67 & 67.0 \\
\hline Women & 33 & 33.0 \\
\hline \multicolumn{3}{|l|}{ Age } \\
\hline $18-44$ & 26 & 26.0 \\
\hline $45-59$ & 35 & 35.0 \\
\hline $60-74$ & 18 & 18.0 \\
\hline $75-90$ & 20 & 20.0 \\
\hline$>90$ & 1 & 1.0 \\
\hline \multicolumn{3}{|l|}{ Education level } \\
\hline Not in school & 11 & 11.0 \\
\hline Elementary school & 19 & 19.0 \\
\hline Junior high school & 18 & 18.0 \\
\hline High school & 33 & 33.0 \\
\hline College & 19 & 19.0 \\
\hline \multicolumn{3}{|l|}{ Job-status } \\
\hline Be at work & 50 & 50.0 \\
\hline Retired & 21 & 21.0 \\
\hline Not at work & 29 & 29.0 \\
\hline \multicolumn{3}{|c|}{ Duration of heart failure } \\
\hline$<1$ years & 58 & 58.0 \\
\hline $1-5$ years & 23 & 23.0 \\
\hline$>5$ years & 19 & 19.0 \\
\hline \multicolumn{3}{|c|}{ Experience getting information about heart failure } \\
\hline Ever & 27 & 27.0 \\
\hline Never & 73 & 73.0 \\
\hline \multicolumn{3}{|c|}{ Desire to improve quality of life } \\
\hline Yes & 100 & 100.0 \\
\hline No & 0 & 0.0 \\
\hline
\end{tabular}

Table 2. Descriptive statistics of nurse-patient interaction and self-care readiness $(n=100)$.

\begin{tabular}{lcc} 
Variables & Mean & SD \pm \\
Nurse-patient interaction & 45.27 & 7.678 \\
Self-care readiness & 50.91 & 10.581 \\
\hline
\end{tabular}

Table 3. Pearson correlation results.

\begin{tabular}{|c|c|c|c|c|}
\hline \multicolumn{3}{|c|}{ Correlation analysis } & \multirow{2}{*}{$\begin{array}{l}\text { Nurse-patient interaction } \\
\qquad 1\end{array}$} & \multirow{2}{*}{$\begin{array}{c}\text { Self-care readiness } \\
\qquad 0.557^{* *} \\
0.000\end{array}$} \\
\hline Pearson & Nurse-patient interaction & $\begin{array}{l}\text { Correlation coefficient } \\
\text { Sig.(2-tailed) }\end{array}$ & & \\
\hline & Self-care readiness & $\begin{array}{l}\text { Correlation coefficient } \\
\text { Sig.(2-tailed) }\end{array}$ & $\begin{array}{c}0.557^{* *} \\
0.000\end{array}$ & 1 \\
\hline
\end{tabular}

**Sig. 0.01 (2-tailed). 
value of the correlation coefficient between the two variables is 0.557 with a positive value indicating that there is a unidirectional relationship between patient-nurse interaction and self-care readiness. This means that the higher the patient nurse's interaction, the greater the patients' readiness to care for themselves, and vice versa. The value of the correlation coefficient is 0.557 , and this shows that the level of closeness of the relationship between these two variables is in the medium category with a significant relationship.

Based on the principles of readiness, all aspects of interaction development mutually influence readiness. ${ }^{4}$ The interaction between nurse and patient referred to in this study is an interaction that was carried out using a patient-centered care approach. Involving patients in care helps patients to understand their health conditions so as to increase their readiness to care for themselves. ${ }^{23}$ Involving the patient as in decision making will lead to better self-care management by increasing motivation and involvement in care. ${ }^{24}$

Furthermore, the interaction between nurses and patients, help prepare patients to care for themselves after leaving the hospital. The relationship between nurses and patients effectively requires the involvement of a genuine personal and emotional involvement. ${ }^{25}$ Another important element of patient-centered care is providing complete information to patients regarding all aspects of their care. Information and education can help facilitate autonomy and self-care. ${ }^{21}$ The results of this study showed that nurses as educators can provide information and skills to patients in the intensive care room, to take care of themselves at home. ${ }^{24}$ Families can also contribute to helping with self-care. ${ }^{25}$ Therefore, it is believed that patients and their families are better prepared and able to carry out proper self-care before leaving the hospital, thereby reducing the rehospitalization rate of heart failure patients.

\section{Conclusions}

This study focuses on the correlation between nurse-patient interactions with the readiness of nurses to provide adequate knowledge for patients with heart failure to care for themselves. The study indicated that the nurse-patient interaction increases patients' readiness in self-care. The results of this study showed that the provision of information and skills as a nurse-patient interaction in carrying out nursing interventions increases the readiness of patients to care for themselves before leaving the hospital improves the quality of life and reduces rehospitalization rates.
Correspondence: Alfrina Hany, School of Nursing, Faculty of Medicine, Universitas Brawijaya, Jl. Puncak Dieng, Kunci, Kalisongo, Kec. Dau, Malang, East Java 65151, Indonesia. Tel. +62.341569117 - Fax: +62.341564755

E-mail: hanie.fk@ub.ac.id

Key words: Nurse-patient interaction; self-care readiness; patientcentered care.

Acknowledgement: The authors are grateful to the Faculty of Medicine, Universitas Brawijaya, Malang, Indonesia, for their support and encouragement.

Contributions: All authors contributed equally to this research.

Conflict of interest: The authors declared that there were no potential conflicts of interest

Ethics Approval: This research was carried out after obtaining ethical permission from the Health Research Ethics Commission of the Faculty of Medicine, Universitas Brawijaya No. 265/EC/KEPK/ $10 / 2019$.

Conference presentation: Part of this study was presented at the $1^{\text {st }}$ International Nursing and Health Sciences Symposium, November $13^{\text {th }}$ to $15^{\text {th }} 2020$, Brawijaya University, Malang, Indonesia.

Received for publication: 20 January 2021.

Accepted for publication: 15 March 2021.

o Copyright: the Author(s), 2021

Licensee PAGEPress, Italy

Journal of Public Health Research 2021;10:2229

doi:10.4081/jphr.2021.2229

This work is licensed under a Creative Commons Attribution NonCommercial 4.0 License (CC BY-NC 4.0).

\section{References}

1. Kessing D, Denollet J, Widdershoven J, et al. Self-care and health-related quality of life in chronic heart failure: A longitudinal analysis. Eur J Cardiovasc Nurs 2017;16:605-13.

2. Ponikowski P, Anker SD, AlHabib KF, et al. Heart failure: preventing disease and death worldwide. ESC Heart Fai. 2014;1:4-25.

3. Bakari Salehe DN. Good quality interaction between the registered nurse and the patient. 2016;48.

4. Slamento. [Belajar dan Faktor-Faktor Yang Mempengaruhinya (Learning and the factors that affect it)].[Book in Indonesian] Jakarta: Rineka Cipta; 2013.

5. Casu G, Gremigni P, Sommaruga M. The Patient-Professional Interaction Questionnaire (PPIQ) to assess patient centered care from the patient's perspective. Patient Educ Couns 2019;102:126-33.

6. Park M, Giap TTT, Lee M, et al. Patient- and family-centered care interventions for improving the quality of health care: A review of systematic reviews. Int J Nurs Stud 2018;87:69-83.

7. Austin BT, Bonomi A, Hindmarsh M, et al. Improving chronic illness care: Translating evidence into action. Health Aff 2003;20:64-78.

8. Bodenheimer T, Wagner EH, Grumbach K. Improving primary care for patients with chronic illness. JAMA 2002;288:1775-9.

9. Cramm JM, Nieboer AP. Chronically ill patients' self-management abilities to maintain overall well-being: What is needed 
to take the next step in the primary care setting? BMC Fam Pract 2015;16:1-8.

10. Happ MB, Garrett K, Thomas DDV, et al. Nurse-patient communication interactions in the intensive care unit. Am J Crit Car. 2011;20:1-21.

11. Kaawoan AYA. [Hubungan self-care dan depresi dengan kualitas hidup pada pasien HF di RSUD Prof DR R.D Kandou Manado. Hub self-care dan depresi dengan kualitas hidup pada pasien HF di RSUD Prof DR RD Kandou Manad (The relationship between self-care and depression with quality of life in HF patients at RSUD Prof. DR R.D Kandou Manado. The hub of self-care and depression with quality of life in HF patients at RSUD Prof. DR RD Kandou Manad)].[in Indonesian]. Depok: Universitas Indonesia; 2012.

12. Sekarsari R, Suryani AI. [Gambaran aktivitas sehari-hari pada pasien gagal jantung kelas II dan III di poli jantung rsu kabupaten tangerang (Overview of daily activities in class II and III heart failure patients in cardiac clinic, Tangerang district)].[Article in Indonesian]. Jurnal JKFT 2016;1:1-7.

13. Karavidas A, Lazaros G, Tsiachris D, et al. Aging and the cardiovascular system. Hell J Cardiol 2010;51:421-7.

14. Tatukude C, Rampengan SH, Panda AL. [Hubungan tingkat depresi dan kualitas hidup pada pasien gagal jantung (Relationship between depression level and quality of life in heart failure patients)].[Article in Indonesian]. Jurnal E-Klinik 2016;4:115-20.

15. Zamanzadeh V, Valizadeh L, Howard AF, et al. A Supportiveeducational intervention for heart failure patients in Iran: The effect on self-care behaviours. Nurs Res Pract 2013;2013:1-7.

16. Hany A, Cahyanti T. Effect MOTENSI apps on adherence behavior taking antihipertensive drugs in patients with hypertension in malang city health care. Malang: Jurusan Keperawatan FK UB; 2020.

17. Gremigni P, Casu G, Sommaruga M. Patient education and counseling dealing with patients in healthcare: A self-assessment tool. Patient Educ Couns 2016;99:1046-53.
18. Arumsari DP, Emaliyawati E, Sriati A. [Hambatan komunikasi efektif perawat dengan keluarga pasien dalam perspektif perawat (Barriers to effective communication between nurses and the patient's family in the perspective of the nurse)].[Article in Indonesian]. J Pendidik Keperawatan Indones 2016;104-14.

19. Lestari CA, Hany A. The effect of "MOTENSI" application on low salt diet adherence in hypertensive patient at the Malang City public health center. Malang: Jurusan Keperawatan FK UB; 2020.

20. Restada EJ. [Hubungan Lama Menderita dan Komplikasi Diabetes Melitus Dengan Kualitas Hidup Pada Penderita Diabetes Melitus di Wilayah Puskesmas Gatak Sukoharjo (The relationship of long suffering and complications of diabetes mellitus with quality of life for diabetes mellitus patients in the Gatak Sukoharjo Community Health Center)].[in Indonesian]. Surakarta: Universitas Muhammadiyah Surakarta; 2016.

21. Rantung J, Yetti K, Herawati T. [Hubungan self-care dengan kualitas hidup pasien diabetes melitus ( $\mathrm{dm}$ ) di persatuan diabetes indonesia (persadia) cabang cimahi (The relationship of self-care with the quality of life of patients with diabetes mellitus (DM) in the Indonesian Diabetes Association (Persadia), Cimahi branch]).[Article in Indonesian]. Jurnal Skolastik Keperawatan 2015;1:38-51.

22. Ilioudi S, Lazakidou A, Tsironi M. Information and communication technologies for better patient self-management and self-efficacy. Int J Electron Healthc 2010;5:327-39.

23. Jardien-Baboo S, van Rooyen D, Ricks E, et al. Perceptions of patient-centred care at public hospitals in Nelson Mandela Bay. Heal SA Gesondheid 2016;21:397-405.

24. Son Y-J, Lee Y-M, Kim EY. How do patients develop self-care behaviors to live well with heart failure?: A focus group interview study. Collegian 2019;26:448-56.

25. Nkambule BS, Lee-Hsieh J, Liu CY, et al. The relationship between patients' perception of nurse caring behaviors and tuberculosis stigma among patients with drug-resistant tuberculosis in Swaziland. Int J Africa Nurs Sci 2019;10:14-8. 